\title{
Fundamental Factors in Marital Satisfaction: An Assessment of Brazilian Couples
}

\author{
Keila Rebello, Mauro Dias Silva Junior, Regina Célia Sousa Brito \\ Federal University of Pará-UFPA, Belém, PA, Brazil \\ Email: keilarebello@gmail.com
}

Received 16 February 2014; revised 14 March 2014; accepted 12 April 2014

Copyright $@ 2014$ by authors and Scientific Research Publishing Inc.

This work is licensed under the Creative Commons Attribution International License (CC BY). http://creativecommons.org/licenses/by/4.0/

(c) (i) Open Access

\begin{abstract}
In this research we aimed to study how couples perceive their marital relationships. More specifically, our goal was to ascertain the way middle class couples, living in Brazil, evaluate the quality of their current marital relationships. 100 cohabiting couples were asked to fulfill the Marriage and Relationship Questionnaire (MARQ), and we found that 86\% lived together for $\mathbf{1 2 . 6 2}$ years on average and declared to be satisfied with their relationship. Jealousy, partnership and love were found to be the most relevant factors for marital satisfaction, thereby reaffirming the Evolutionary Psychology hypotheses about the omnipresence of love and jealousy as elements of cohesion in humans. Selection for those factors may have occurred from early mankind on, particularly with regard to the establishment and maintenance of affective partnerships.
\end{abstract}

\section{Keywords}

Marital Satisfaction, Jealousy, Love, Evolutionary Psychology

\section{Introduction}

Marital satisfaction is a complex and multidimensional phenomenon (Mósmann, Wagner, \& Féres-Carneiro, 2007), which has been extensively explored by the most diverse scientific fields (Berger \& Kellner, 1970; Gottman, 1993; Feeney \& Noller, 1990, 1992; Singly, 1993; Karney \& Bradbury, 1995; Feeney, 1999; Féres-Carneiro, 1999; Perlin, 2006; Jablonski, 2010; Selcuk, Zayas, \& Hazan, 2010; Mósmann \& Falcke, 2007, 2011; Acevedo, Aron, Fisher, \& Brown, 2012).

Factors of cultural, religious, legal and educational origins, among others, help to shape our ideal of what is necessary for constituting an affective relationship, especially a marital one (Lalonde, Hynie, Pannu, \& Tatla, 2004; Lucas, Parkhill, Wendorf, Imamoglu, Weisfeld, Weisfeld, \& Shen, 2008; Wendorf, Lucas, Imamoglu, Weisfeld, \& Weisfeld, 2011). 
Therefore, the satisfaction of a spouse depends, to some extent, on how well his or her marriage responds to the expectations and duties imposed by the cultural and social spheres.

In western industrialized cultures, the criteria of satisfaction are related to goals of self-gratification or to the ideals of happiness established between spouses. In countries with a more collectivist background, on the other hand, the criteria of satisfaction relate to the way relatives of the spouses are treated, as happens in China, for example (Lalonde, Hynie, Pannu, \& Tatla, 2004).

The spouses estimate their marital satisfaction by keeping track of its costs and benefits, based upon their life's history. That's why the sociocultural context is of great importance in interpersonal relations, acting as a force of ecological adaptability for the individuals, especially in more intimate relationships, as is the case in a marital relationship.

Beyond the intercultural differences in the way marital relationships are evaluated, there are also differences within the same culture that may bring spouses to adopt different criteria for marital satisfaction, influenced by the sociopolitical and cultural contexts of the countries they live in (Lucas et al., 2008) and probably related to the culturally established sexual roles.

By observing the differences pointed out, we seem to have some universal factors that contribute to marital satisfaction. According to Evolutionary Psychology, these factors came about by phylogenesis and interact with the cultural and ecological conditions of the individuals.

Evolutionary Psychology suggests our behavioral repertoire is influenced by the evolution of psychological mechanisms that facilitated the survival and reproduction of our ancestors, in response to problems faced in the environment of evolutionary adaptedness (Tooby \& Cosmides, 1992).

Love, jealousy, attachment and the observation of relationship satisfaction itself, are examples of these mechanisms considered essential for the maintenance of marriage.

Love would be the key to long-term relationships and its presence among the spouses would be the best way of assuring the endurance of the relationship. In this context, love is considered to provide sexual access to the partner, while ensuring his or her sexual fidelity and promoting exclusivity in the relationship by means of mate-guarding like, for example, monopolizing the partner's time and employing sexual jealousy. Furthermore, love would indicate relevant resources for reproduction, like signs of parental investment and sexual and emotional satisfaction (Buss, 2000, 2007).

Fisher $(1998,2000,2004)$ explain love as a complex set of adaptations that can be found in the brain circuitry. A view shared by some other studies of neuroscience like those from Carter (1998), Bartels \& Zecki (2000) and Diamond (2003).

This circuitry is supposed to be made up of three neural systems, all related to human reproduction: lust, romantic love and attachment. The first neural system would have motivated our ancestors to look for sexual gratification by means of sexual intercourse with any partner (Fisher, Aron, Mashek, Li, Strong, \& Brown, 2002) and Fisher (1998, 2000, 2004).

The second system, named romantic-love, commonly known as passion, is characterized, according to Tennov (1979), by obsessive thinking of the loved one (intrusive thinking) and desire of emotional union with the partner or potential partner. Both of these traits are associated with the rising of the levels of dopamine and norepinephrine in the nervous system, while diminishing the level of serotonin (Bartels \& Zecki, 2000; Fisher, 1998). Tennov (1979), Marazziti, Rossi \& Cassano (1999) and Fisher (1998, 2004). This system would have enabled our ancestors to concentrate their energy, time and resources on one individual at a time, safeguarding against eventual wastes in the mating effort.

The third system, named attachment, is characterized by the defense of the territory, food-sharing, keeping close to the loved one, fear of getting separated from the object of attachment, family ties, and other such affiliate behaviors (Fisher, 2000, 2004; Fisher et al., 2002). The attachment system between men and women made us develop enduring affiliate bonds, which are at the origin of what we know today as family ties, contributed to keep partners together for the minimum period of time necessary for generating and raising the children resulting of an affective partnership (Fisher, 2000, 2004; Fisher et al., 2002). This system is supposed to be related to the sensations of peace, security and stability, associated with neuropeptides like oxytocin and vasopressin, both present in long-term relationships.

Hazan and Zeifman (1999) and Diamond (2003) believe that the attachment system was assimilated by our psyche because it contributes to maintain affective partners together, facilitating parental care and maximizing their chances of reproductive success. Selcuk, Zayas and Hazan (2010) state that attachment produces physical 
and psychological benefits, as much as or beyond the benefits provided by marital satisfaction.

Being so, our tendency as hominids to pair bonding and attaching ourselves affectively to our partners, could be seen as an exaptation of the relation infant-caretaker (Diamond, 2003). The role of oxytocin played in the sensations of security and peace from the constitution of the relation mother-child up to the establishment of adult love relationship, could be considered a good argument in favor of this proposition.

Feeney and Noller $(1990,1992)$ and Feeney (1999) propose that the psychological well-being of the members of the family constituted by the couple, and that are intimately related to love, contribute significantly to satisfaction and stability in the marriage.

In the study conducted by Lucas et al. (2008), mentioned before, 1935 couples, having been married for 13.54 years on average, were recruited and interviewed following the snowball technique, coming from countries like the United States $(\mathrm{N}=322)$, Great Britain $(\mathrm{N}=1.031)$, Turkey $(\mathrm{N}=350)$ and China $(\mathrm{N}=232)$. Employing the MARQ scale to estimate satisfaction in the marriage, they found that the key points indicated for marital satisfaction were love and partnership, even though these countries are quite different from each other, culturally speaking, especially China, which is more of the collectivist kind.

Schimiti and Sarzedas (2008), conducted a study with 16 couples in Paraná (state in the south of Brazil), in which they point out love, respect, intimacy and the sharing of common goals, to be the essential elements for a stable marital relationship. Couples were living together for 5 years at least, had completed secondary education and where living in the northern region of Paraná. They were interviewed in 2004, by means of a questionnaire with 13 questions, of which most were of the open kind (quanti-qualitative research), enumerating what they consider to be more relevant for the stability of their relationship. Aspects like love and respect were considered the most important factors for maintaining the marital relationship, while lack of love and unfaithfulness were considered as the main causes for terminating a relationship.

Acevedo, Aron, Fisher and Brown, (2012) establish a link between the quality of the relationship and the physical and psychological well-being of the individuals. They interviewed seventeen middle-aged individuals $(\mathrm{M}=52.85$ years), being 10 men and 7 women, all heterosexuals, married for over 20 years $(\mathrm{M}=21.4)$, most being in their first marriage, Caucasians, living in the metropolitan area of New York (United States) and having completed college education. All seventeen had their brains scanned by means of functional magnetic resonance, whilst visualizing the facial images of their spouses, relatives and close friends. They also completed the Relationship Evaluation Questionnaire (Hendrick, 1988) in order to get the quality of their marital relationship assessed.

While visualizing the facial image of their spouses, the identified cerebral activity was positively correlated with major marital satisfaction. The areas activated were: the ventral tegmental area, associated with the gratification and motivation system; the ventral orbit cortex, also associated with the motivation system; the front insula, associated with empathy; the nucleus striatum terminalis, associated with stress control. Individuals satisfied with their relationship displayed good physical and psychological health.

The inter-relationship between behavior and physiology, in this study, supports the evolutionary proposition that our affective behavior presents consistent indications of our phylogenetic inheritance, with regard to the psychological mechanisms that still lead our demeanor.

Another mechanism involved in the maintenance of affective relationships would be jealousy, for it aims to keep the sexual and affective faithfulness of the partner as well as to stave off competitors, thereby preventing or trying to prevent the termination of the relationship (Daly \& Wilson, 1996; Buss, 2007). Almeida, Rodrigues and Silva (2008) add that mate-guarding, a behavior that shows jealousy at work, indicate that one has interest in the partner and cares about him or her.

On the other hand, Shackelford and Buss (2000) and Shackelford, Goetz and Buss (2005) showed that the excessive use of mate-guarding are precursory signs of marital dissatisfaction, like for example when one of the spouses tries to control or monopolize the time of the other or when he or she threatens to become unfaithful or to punish the partner's unfaithfulness, or resorts to emotional manipulation, all commonly motivated by excessive jealousy.

Romantic love requires some attitudes from the partners that directly affect their level of satisfaction in the relationship (Lucas et al., 2008). For example, homogamy is thought to be essential for building a satisfactory partnership. Russell and Wells (1991); Epstein and Guttman, (1985), Lichter and Carmall (2009); Scharamm, Marshall, Harris and Lee (2011) suggest that people tend to select similar characteristics in partners, like: age group, attractiveness, social class, intelligence, religion, education, physical traits (looks), personality, among 
others.

In the realm of adaptive evolution, marital union is thought to have helped forward our hominine ancestors in procreating and taking care of the offspring. Marital satisfaction is considered important for the good performance of the individuals in these tasks, and would allow for a better adaptability of the children, through inheritance of the psychological mechanisms of observation of satisfaction in the relationship (Lucas et al., 2008).

This way, the observation of satisfaction enables the spouses to continuously evaluate the costs and benefits of the relationship and decide whether it's (still) worthwhile holding on (benefits are greater than the costs to maintain them) or time to look for another partner (Buss \& Shackelford, 1997; Buss, 2007).

Clarifying the underlying factors of our behaviors involved in maintaining our affective relationships, contributes to the general well-being of the individuals in general, aiding them and their family to stay healthy, both physically and psychologically. In the light of this, the goal of the present study is to understand how couples in Pará (state in the north of Brazil) perceive their marital relationships, and try to identify what they consider to be the most relevant factors for marital satisfaction. The results suggest that the level of satisfaction is directly related to the level of homogamy of the partners.

\section{Method}

\subsection{Participants}

One hundred heterosexual couples took part in this study, which declared themselves to be married (65.5\%) or engaged in an enduring relationship (34.5\%), all living in the north of Brazil. The selection criteria were: older than 18 years; living together for at least 3 years, the average duration of the marriages being 12.62 years $(\mathrm{N}=$ $198, \mathrm{SD}=9.573$. The average age of the men was 39.92 years while that of the women was 37.08 years.

All the participants had a high school education $(\mathrm{N}=179)$ while $(40.2 \%)$ had completed college and $(8.4 \%)$ were postgraduates.

Ninety three percent of the couples $(\mathrm{N}=186)$ declared themselves to be religious, of which $65.1 \%$ were Catholics and 19.9\% Protestants. The average income of the couples was R\$3,088.00, starting from R\$300.00 up to $\mathrm{R} \$ 21,000.00$. With regard to the socio-economic status, the average of the sample was 34.13 points $(\mathrm{N}=$ 100 , SD $=17,725)$, which is of medium level according to Hollingshead (1975).

\subsection{Procedure}

Participants were selected randomly on the campus of a public university in the north of Brazil. Initially by picking out individuals using wedding rings and subsequently by snowball sampling. They responded anonymously to the questionnaires, in locations chosen by them, either in the presence of the researcher or by taking the questionnaires home and returning them in up to one week later at the same location where they were handed to them. The research was initiated after approval of the Ethics Committee of the University. All participants signed a Free and Clarified Consent Term.

\subsection{Instruments}

For the socio-demographic characterization we employed the Adapted Scale of Socio Economic Status Assessment (Hollingshead, 1975), which consists of a questionnaire that aims to identify the socioeconomic status of the couples by means of the following factors: gender, marital status, education level and occupational prestige.

The second instrument was the Marriage and Relationships Questionnaire-MARQ (Russell \& Wells, 1993), widely tested with couples in various countries (Lucas et al., 2008) but new in Brazil. The MARQ is a Likert-type scale, with five choices of answers, for the greater part of its 184 questions, containing 12 subscales (12 factors) that assess the marital satisfaction of the participants by comparing their answers to the twelve scales that make up the instrument. The answers can score 1 to 5 points, where 1 stands for extremely dissatisfied and 5 for extremely satisfied. The scores of husbands and wives were first summed up then divided by 2, in order to obtain the average of the couples for each factor.

\subsection{Data Analysis}

The data was statistically analyzed by means of the Statistic Analysis Program. We run descriptive analyses 
(frequency, averages and standard deviations); Student's t Test in order to obtain independent samples for the comparison between the averages of the spouses; Spearman's Correlation Test, in order to show the degree of relationship between the variable gender in the answers to the satisfaction scale.

\section{Results}

\subsection{Index of Couple Satisfaction}

With regard to the general level of marital satisfaction, $86 \%$ of couples were considered satisfied, $13 \%$ very satisfied and $1 \%$ dissatisfied.

The major raw scores of couples were seen on the sexual jealousy scale $(\mathrm{M}=3.6, \mathrm{SD}=1.05)$, followed by the partnership scale $(\mathrm{M}=3.46, \mathrm{SD}=1.92)$ and on the love scale $(\mathrm{M}=3.38, \mathrm{SD}=1.98)$, thereby pinpointing the most important factors for marital satisfaction. These results show that the couples perceive and evaluate satisfaction in the relationship in a quite similar fashion.

According to Student's t tests for independent measures, no significant differences were found by comparing the averages of the answers of the men and women to the factors of the MARQ scale, if we take out the roles scale, as can be seen in Table 1 .

\subsection{Correlations between Scores by Men and Women}

As we can see in Table 2, there are positive correlations on practically all the scales. In other words, the higher the score on the wives' scale, the higher the score on the husbands' scale.

\section{Discussion}

In this study we found that Brazilian couples were satisfied with their marital relationship and that sexual jealousy is considered the most important factor for marital satisfaction. The homogamous couples were the most satisfied.

This assessment, in which the multidimensionality of the factors involved in marital satisfaction was taking into account, was realized following a threefold perspective: the perception of one's own satisfaction, the perception of the partner's satisfaction and the partner's perception of the relationship itself, as being a third entity, a generator of positive reaffirmations of the couple's love and satisfaction. This was possible because of the instrument used to measure the satisfaction, the MARQ Scale, employed for the first time in Brazil and still unmatched by any other instrument, in terms of efficiency.

Table 1. Description of the levels of statistic significance between the answers of the genders to the satisfaction scales.

\begin{tabular}{ccc}
\hline Scale & Values of $\mathbf{t}$ and $\mathbf{~}$ & $\boldsymbol{p}$ \\
Love & $\mathrm{t}_{198}=-1.119, \mathrm{r}=0.079$ & 0.264 \\
Partnership & $\mathrm{t}_{198}=-1.267, \mathrm{r}=0,0896$ & 0.207 \\
Sexual Jealousy & $\mathrm{t}_{198}=-0.155, \mathrm{r}=0,011$ & 0.877 \\
Roles & $\mathrm{t}_{198}=0.000, \mathrm{r}=0$ & 1.00 \\
Problems with the Relationship & $\mathrm{t}_{198}=0.000, \mathrm{r}=0$ & 1.00 \\
Personal Problems & $\mathrm{t}_{198}=0.000, \mathrm{r}=0,040$ & 1.00 \\
Attractiveness & $\mathrm{t}_{198}=0.569, \mathrm{r}=0,040$ & 0.570 \\
Values & $\mathrm{t}_{198}=-0.492, \mathrm{r}=0,034$ & 0.623 \\
Family Ties & $\mathrm{t}_{198}=0.384, \mathrm{r}=0,027$ & 0.701 \\
Circumstancial Problems & $\mathrm{t}_{198}=-0.194, \mathrm{r}=0,013$ & 0.846 \\
Problems with the Partner & $\mathrm{t}_{198}=0.220, \mathrm{r}=0,0156$ & 0.826 \\
Conciliation & $\mathrm{t}_{198}=0,383, \mathrm{r}=0,027$ & 0.702 \\
\hline
\end{tabular}


Table 2. Spearman's Correlation test, between the scales of men and women, indicates the following results.

\begin{tabular}{cccc}
\hline Scale & Rho & $\boldsymbol{p}$ & $\mathbf{r}^{2}$ \\
\hline Partnership & 0.574 & 0.001 & 0.329 \\
Roles & 0.500 & 0.001 & 0.250 \\
Love & 0.673 & 0.001 & 0.452 \\
Problems with Partner & 0.754 & 0.001 & 0.568 \\
Values & 0.885 & 0.001 & 0.783 \\
Family Ties & 0.854 & 0.001 & 0.729 \\
Circumstancial Problems & 0.963 & 0.001 & 0.927 \\
Attractiveness & 0.922 & 0.001 & 0.850 \\
Sexual Jealousy & 0.925 & 0.001 & 0.855 \\
Conciliation & 0.925 & 0.001 & 0.855 \\
Problems with Relationships & 1.000 & 0.001 & 1.0 \\
Personal Problems & 1.000 & 0.001 & 1.0 \\
\hline
\end{tabular}

Results obtained allow classifying satisfaction as a good predictor of stability in the relationship of couples, emphasizing that they've been together for about 12.63 years on average, which is time enough for evaluating the characteristics of the partner and measure the degree of investment made by both.

Factors as jealousy, partnership and love were identified as the major sources of relational satisfaction, given their high raw scores. They also reflect partners' faith in each other and show that satisfaction gets higher as partners grow closer emotionally and partnership gets stronger (Norgren et al., 2004). These factors moreover indicate the spouses' positive assessment of their relationship, considered, in this perspective, as being more beneficial than costly. They show that jealousy yields adaptability to the spouses, since it also indicates the level of commitment of the partner in the relationship, thereby contributing to the strengthening of love within the couple.

Quite differently from what has been evidenced in other cultures, in this Brazilian sample, sexual jealousy has been given more importance than the dimensions of love and partnership. This result could be related to religious aspects (indissolubility of marriage), taking into account that a big part of the sample is formed by religious people. It brings forward some peculiarities of the Brazilian culture when compared to the other countries where the MARQ has already been tested.

These results reinforce the conjecture that both jealousy and love are components that have evolved phylogenetically from marital satisfaction, since they can be seen as culturally homogenous all over the world, independently of country, culture or whatever other variables, since these components are considered essential in relational satisfaction under any circumstances.

We also investigated if the couples that had more similar traits (homogamous) are more satisfied than those who had less similar traits. The results of the responses of the MARQ regarding this question are positive, if we look at the indexes of satisfaction between the couples in Table 1, as well as at the characteristics like age group, social class (the majority being middle class), religious orientation and education level.

However, we were not able to prove the hypothesis that similarity will increase over time (Wilson \& Cousins, 2003), since this would need a longitudinal research later on to prove this; a research that cannot take place, given that the participants are all anonymous.

\section{Conclusions}

The results found in this study strengthen the presuppositions of Evolutionary Psychology with regard to the omnipresence of love and jealousy as uniting factors in the establishment of couples and/or affective partnerships among hominids, from the age of our ancestors up to today. Men and women of the most diverse cultures from around the world take care of their relationships and keep united by mechanisms molded into our psychology by phylogeny. 
Even though thousands of years have passed, our behavior in modern society is still being directed by these same ancient mechanisms. In spite of the fact that we think we are rational beings, aware of our choices, these are all still influenced by our subconscious mechanisms.

\section{Acknowledgements}

The authors express their gratitude for the collaboration and support of the researchers Glenn and Carol Weisfeld (University of Detroit-USA) in the elaboration of this study (MARQ Scale) and especially to Federal University of UFPA (PROPESP/FADESP) for its financial support on this publication, as they are to Giovanni Taytelbaum for his care with translating this material and to their colleagues from GEAPE-UFPA and specially to participants couples and to the reviewers.

\section{References}

Acevedo, B., Aron, A., Fisher, H., \& Brown, L. (2012). Neural Correlates of Marital Satisfaction and Well-Being: Reward, Empathy, and Affect. Clinical Neuropsychiatry, 9, 20-31.

Almeida, T., Rodrigues, K. R. B., \& Silva, A. A. (2008). O ciúme romântico e os relacionamentos amorosos heterossexuais contemporâneos. Estudos de Psicologia, 13, 83-90.

Bartels, A., \& Zecki, S. (2000). The Neural Basis of Romantic Love. Neuroreport, 11, 1-6. http://dx.doi.org/10.1097/00001756-200011270-00046

Berger, P., \& Kellner, H. (1970). Marriage and the Construction of Reality. In H. P. Dreitzel (Ed.), Patterns of Communicative Behaviour Recent Sociology, $n^{\circ} 2$.

Buss, D. M. (2000). A paixão perigosa: por que o ciúme é tão necessário quanto o amor e o sexo, tradução Myriam Campelo, Objetiva (3rd ed). Tradução de The Dangerous Passion.

Buss, D. M. (2007). The Evolution of Human Mating. Acta Psychologica Sinica, 39, 502-512.

Buss, D. M., \& Shackelford, T. K. (1997). From Vigilance to Violence: Mate Retention Tactics in Married Couples. Journal of Personality and Social Psychology, 72, 346-361. http://dx.doi.org/10.1037/0022-3514.72.2.346

Carter, C. S (1998). Neuroendocrine Perspectives on Social Attachment and Love. Psychoneuroendocrinology, 23, 779-818. http://dx.doi.org/10.1016/S0306-4530(98)00055-9

Daly, M., \& Wilson, M. (1996). Evolutionary Psychology and Marital Conflict: The Relevance of Stepchildren. In D. M. Buss, \& N. Malamuth (Eds.), Sex, Power, Conflict: Feminist and Evolutionary Perspectives (pp. 9-28). New York: Oxford University Press.

Diamond, L. M. (2003). What Does Sexual Orientation Orient? A biobehavioral Model Distinguishing Romantic Love and Sexual Desire. Psychological Review, 110, 173-192. http://dx.doi.org/10.1037/0033-295X.110.1.173

Epstein, E., \& Guttman, R. (1985). Mate Selection in Man: Evidence, Theory and Outcome. Social Biology, 31, $351-361$.

Feeney, J. A. (1999). Adult Attachment, Emotional Control and Marital Satisfaction. Personal Relationships, 6, 169-185. http://dx.doi.org/10.1111/j.1475-6811.1999.tb00185.x

Feeney, J. A., \& Noller, P. (1990). Attachment Style as Predictor of Adult Romantic Relationships. Journal of Personality and Social Psychology, 58, 281-291. http://dx.doi.org/10.1037/0022-3514.58.2.281

Feeney, J. A., \& Noller, P. (1992). Attachment Style and Romantic Love: Relationship Dissolution. Australian Journal of Psychology, 44, 69-74. http://dx.doi.org/10.1080/00049539208260145

Féres-Carneiro, T., \& Féres-Carneiro, T. (1999). Conjugalidade: um estudo sobre as diferentes dimensões da relação amorosa heterossexual e homossexual. Casal e família: Entre a tradição e a transformação (pp. 96-117).

Fisher, H. (1998). Lust, Attraction and Attachment in Mammalian Reproduction. Human Nature, 9, 23-52. http://dx.doi.org/10.1007/s12110-998-1010-5

Fisher, H. (2000). Lust, Attraction, Attachment: Biology and Evolution of the Three Primary Emotions Systems for Mating, Reproduction and Parenting. Journal of Sexual Education and Therapy, 25, 96.

Fisher, H. (2004). Why We Love: The Nature and Chemistry of Romantic Love. New York: Henry Holt and Company.

Fisher, H., Aron, A., Mashek, D., Li, H., Strong, G., \& Brown, L. (2002). Defining the Brain Systems of Lust, Romantic Attraction and Attachment. Archives of Sexual Behavior, 31, 5 413-419. http://dx.doi.org/10.1023/A:1019888024255

Gottman, J. M. (1993). The Roles of Conflict Engagement, Escalation, and Avoidance in Marital Interaction: A Longitudinal View of Five Types of Couples. Journal of Consulting and Clinical Psychology, 61, 6-15.

http://dx.doi.org/10.1037/0022-006X.61.1.6 
Hazan, C., \& Zeifman, D. (1999). Pair-Bonds as Attachments: Evaluating the Evidence. In J. Cassidy, \& P. R. Shaver (Eds.), Handbook of Attachment Theory and Research (pp. 336-354). New York: Guilford.

Hollingshead, A. B. (1975). Department of Sociology. Unpublished Working Paper, New Havens, CT: Yale University.

Jablonski, B. (2010). A divisão de tarefas domésticas entre homens e mulheres no cotidiano do casamento. Psicologia: Ciência e Profissão, 30, 262-275. http://dx.doi.org/10.1590/S1414-98932010000200004

Karney, B. R., \& Bradbury, T. N. (1995). The Longitudinal Course of Marital Quality and Stability: A Review of Theory, Methods, and Research. Psychological Bulletin, 118, 3-34. http://dx.doi.org/10.1037/0033-2909.118.1.3

Lalonde, R. N., Hynie, M., Pannu, M., \& Tatla, S. (2004). The Role of Culture in Interpersonal Relationships: Do Second Generation South Asian Canadians Want a Traditional Partner? Journal of Cross-Cultural Psychology, 35, 503-524. http://dx.doi.org/10.1177/0022022104268386

Lucas, T., Parkhill, M. R., Wendorf, C. A., Imamoglu, E. O., Weisfeld, C. C., Weisfeld, G. E., \& Shen, J. C. (2008). Cultural and Evolutionary Components of Marital Satisfaction: A Multidimensional Assessment of Measurement Invariance. Journal of Cross-Cultural Psychology, 39, 109-123. http://dx.doi.org/10.1177/0022022107311969

Marazziti, D., Akiskal, H. S., Rossi, A., \& Cassano, G. B. (1999). Alteration of the Platelet Serotonin Transporter in Romantic Love. Psychological Medicine, 29, 741-745.

Mósmann, C., \& Falcke, D. (2011). Conflitos conjugais: motivos e frequência. motivos e frequência. Revista da SPAGESP, 12, 5-16.

Mósmann, C., Wagner, A., \& Féres-Carneiro, T. (2007). Qualidade Conjugal: Mapeando Conceitos. Paidéia, 16, $315-325$.

Norgren, M. B. P., Souza, R. M., Kaslow, F., Hammerschmidt, H., \& Sharlin, S. A. (2004). Satisfação conjugal em casamentos de longa duração: Uma construção possível. Estudos de Psicologia (Natal), 9, 575-584.

Perlin, G. D. B. (2006). Casamentos contemporâneos: um estudo sobre os impactos da interação família-trabalho na satisfação conjugal. 2006. $284 f$ (Doctoral Dissertation, Tese (Doutorado em Psicologia)—Universidade de Brasília, Brasília, 2006. Disponível em http://repositorio. bce.unb.br/handle/10482/9274

Russell, R. J. H., \& Wells, P. A. (1991). Personality Similarity and Quality of Marriage. Personality and Individual Differences, 12, 407-412. http://dx.doi.org/10.1016/0191-8869(91)90057-I

Russell, R. J. H., \& Wells, P. A. (1993). Marriage and the Relashionship Questionnaire: MARQ Handbook. Sevenoaks: Hodder and Stoughton.

Scharamm, D. G., Marshall, J. P., Harris, V. W., \& Lee, R. L. (2011). Religiosity, Homogamy and Marital Ajustment. Journal of Family Issues, 33, 246-268.

Schimiti, J. A., \& de Melo Sarzedas, L. P. (2008). Relacionamento estável na visão de casais. Terra e Cultura, 46, 24.

Selcuk, E., Zayas, V., \& Hazan, C. (2010). Beyond Satisfaction: The Role of Attachment on Marital Functioning. Journal of Family Theory \& Review, 2, 258-279. http://dx.doi.org/10.1111/j.1756-2589.2010.00061.x

Shackelford, T. K., \& Buss, D. M. (2000). Marital Satisfaction and Spousal Cost Infliction. Personality and Individual Differences, 28, 917-928. http://dx.doi.org/10.1016/S0191-8869(99)00150-6

Shackelford, T. K., Goetz, A. T., \& Buss, D. M. (2005). Mate Retention in Marriage: Further Evidence of Reliability of the Mate Retention Inventory. Personality and Individual Differences, 39, 415-425.

http://dx.doi.org/10.1016/j.paid.2005.01.018

Tennov, D. (1979). Love and Limmerence: The Experience of Being in Love. New York: Stein and Day.

Tooby, J., \& Cosmides, L. (1992). The Psychological Foundations of Culture. In J. H. Barkow, L. Cosmides, \& J. Tooby (Eds.), The Adapted Mind: Evolutionary Psychology and the Generation of Culture. Oxford: Oxford University Press.

Wendorf, C. A., Lucas, T., Imamoglu, E. O., Weisfeld, C. C., \& Weisfeld, G. E. (2011). Sex Differences and Similarities in Married Couples: Patterns across and within Cultures. Journal of Cross-Cultural Psychology, 42, 340-354.

Wilson, G. D., \& Cousins, J. M. (2003). Partner Similarity and Relationship Satisfaction: Development of a Compatibility Quotient. Sexual and Relationship Therapy, 18, 161-170. http://dx.doi.org/10.1080/1468199031000099424 